\title{
6 The Prohibition of Arbitrary \\ DEPRIVATION OF NATIONALITY UNDER \\ INTERNATIONAL LAW AND EU LAW: NEW \\ Perspectives
}

Tamás Molnár

\subsection{Setting the Scene: The Relevance of the Issue}

Arbitrary deprivation of nationality is of serious concern to the international community. Such acts of the State effectively place the persons concerned in a 'legal vacuum' regarding the enjoyment of their human rights and fundamental freedoms, ${ }^{1}$ in particular in areas of education, housing, employment, health and social security since these persons are put in a situation of high vulnerability to human rights violations. In case of denationalization, the persons affected become non-citizens with respect to the State that deprived them of their nationality (either still possessing another nationality, and consequently becoming aliens in their motherland, or in the worst case the individual is rendered stateless). Persons arbitrarily deprived of nationality may thus be exposed to poverty, social exclusion, and limited legal capacity. ${ }^{2}$ Nevertheless, this aspect of nationality law is somewhat neglected by legal and socio-political literature. The history and current practice as well as the magnitude of the problem would nonetheless require closer attention and concerted action of the international community, but principally tangible efforts from the individual States. Even after the creation of the United Nations, in the last couple of decades, racial and ethnic minorities have been arbitrarily stripped of their nationality and rendered stateless in a considerable number of countries around the world. ${ }^{3}$

* Adjunct Professor, Corvinus University of Budapest, Institute of International Studies; Head of Unit, Ministry of Interior of Hungary, Department of EU Cooperation, Migration Unit. E-mail: tamas.molnar@bm.gov.hu. This article was supported by the János Bolyai Research Scholarship of the Hungarian Academy of Sciences.

1 This is impressively illustrated by the Report of the UN Secretary-General of 19 December 2011, which analyses the impact of arbitrary deprivation of nationality on the enjoyment of human rights, including civil, political, economic, social and cultural rights (A/HRC/19/43).

2 UN Human Rights Council, resolution 20/5 of 16 July 2012, operative Para. 7.

3 Examples for such en masse denationalization include the following: 1) In Bhutan, extremely burdensome requirements of successive nationality acts in 1977 and 1985 resulted in the arbitrary deprivation of nationality of over 100,000 southern Bhutanese of Nepali origin and their forced removal from Bhutan to Nepal in the early 1990s. 2) Tens of thousands of black Mauritanians were stripped of citizenship documents, 
The present paper first highlights the role of international law in regulating nationality (Part 6.2) and the international legal framework prohibiting the deprivation of nationality, starting with human rights conventions in which this prohibition appears as the negative aspect of everyone's right to nationality; examining thereafter specific statelessness conventions such as the 1961 UN Convention on the Reduction of Statelessness or the 1997 European Convention on Nationality (Part 6.3). Subsequently, it continues to delineate different situations amounting to arbitrariness when deciding on the withdrawal of a nationality (Part 6.4), including the discussion of possible ex post effective remedies (Part 6.5). As a relatively new phenomenon, even European Union (EU) law has not been left untouched by this issue. Despite the lack of explicit EU competences in this regard, the obligation not to arbitrarily deprive someone's nationality has been completed with EU law requirements, principally stemming from the fundamental character of EU citizenship (Part 6.6). Remarkably, convergences between UN (soft) law and EU (case) law can be observed in the light of the recent developments (Part 6.7).

\subsection{State Sovereignty and Regulating Nationality: The Basics}

Even if 'nationality' is an issue of interest for public international law, its definition and content are still primarily determined by the States. ${ }^{4}$ Under international law, the traditional point of departure is that nationality matters (e.g. acquisition, loss, renunciation and deprivation of nationality) fall within the domestic jurisdiction (domaine resérvé) of States. This doctrine was already reaffirmed by the Permanent Court of International Justice (PCIJ) in its advisory opinion on Nationality Decrees Issued in Tunis and Morocco (1923) as follows: in the present state of international law, questions of nationality are, in the opinion of the Court, in principle within this reserved domain'. ${ }^{5}$ However, the PCIJ did not stop there and left a door open, having also referred to possible developments of

then forcibly expelled from their country in 1989, who have been living in a situation of de facto statelessness in Senegal ever since. 3) In Zimbabwe, a nationality law adopted in 2002 obliged anyone presumed to have any other nationality to renounce the claim to that second nationality or else lose Zimbabwean citizenship. This new law was applied specifically against particular ethnic groups with surnames considered 'nonZimbabwean.' Source: Open Society Institute, Citizenship and Equality in Practice: Guaranteeing Non-Discriminatory Access to Nationality, Protecting the Right to be Free from Arbitrary Deprivation of Nationality and Combating Statelessness, November 2005, pp. 10-11.

4 See for instance P. Weis, Nationality and Statelessness in International Law, Stevens \& Sons, London, 1956, pp. 29-32; H.F. van Panhuys, The Rôle of Nationality in International Law, A.W. Sijthoff, Leiden, 1959, pp. 37-38; M.N. Shaw, International Law, 5th edition, Cambridge University Press, Cambridge, 2003, pp. 574, 585; I. Brownlie, Principles of Public International Law, Oxford University Press, Oxford, 2003, pp. 373-374; O. Dörr, 'Nationality', in W. Rüdiger (Ed.), The Max Planck Encyclopedia of Public International Law, Oxford University Press, 2012.

5 Nationality Decrees Issued in Tunis and Morocco (French Zone) on 8th November, 1921, PCIJ, Ser. B. No. 4, 1923, Para. 40. 
international law in the course of time when it added that ' $\mathrm{t}]$ he question whether a certain matter is or is not solely within the jurisdiction of a State is an essentially relative question; it depends upon the development of international relations. ${ }^{6}$ Furthermore, not only may the future developments in international law have an impact on this issue, but already at the time of the dispute the Court did not consider this State prerogative to be absolute when it stated: 'in a matter which, like that of nationality, is not, in principle, regulated by international law, the right of a State to use its discretion is nevertheless restricted by obligations which it may have undertaken towards other States ${ }^{77}$ and identified limits fixed by international law, embracing both customary law and general as well as particular treaty law. ${ }^{8}$ A couple of years later the president of the Mexican-French Claims Commission reconfirmed this approach in the Georges Pinson case (1928) holding that notwithstanding States' exclusive domestic jurisdiction in matters of nationality, this sovereignty can be limited by customary and treaty law rules of international law. ${ }^{9}$ This position is now settled case-law as evidenced by the case-law of other human rights courts (e.g. the Inter-American Court of Human Rights). ${ }^{10}$

It was the 1930 Hague Convention on Certain Questions Relating to the Conflict of Nationality Laws ${ }^{11}$ that first codified the above approach, which - besides reconfirming nationality issues as belonging to the realm of States' domestic jurisdiction - set forth certain limitations stemming from international law on invoking a certain nationality vis$\grave{a}$-vis other States, i.e. on the eventual effects of nationality on the international plane. By virtue of Articles 1 and 2 of the 1930 Hague Convention,

[i]t is for each State to determine under its own law who are its nationals. This law shall be recognised by other States in so far as it is consistent with interna-

6 Ibid., Para. 41 (emphasis added).

7 Ibid., Para. 41 (emphasis added).

8 Ibid., Para. 38.

9 Georges Pinson (France) v. United Mexican States, 19 October 1928, UN Reports of International Arbitral Awards, Volume V, p. 364. In the French original: '[...] tout Etat est en principe, compétent pour fixer souverainement les conditions dont dépendront l'acquisition et la perte de sa nationalité et que tout tribunal international doit naturellement (sauf le cas de restrictions posées à la souveraineté des Etats litigants par le droit international écrit ou coutumier) acquiescer aux réglementations qu'ont fixées les Etats en question.'

10 See e.g. Proposed Amendments to the Naturalization Provision of the Constitution of Costa Rica, InterAmerican Court of Human Rights, Advisory Opinion OC-4/84 of January 19, 1984, Series A No. 4, Para. $32:$ ' $[\ldots]$ despite the fact that it is traditionally accepted that the conferral and regulation of nationality are matters for each state to decide, contemporary developments indicate that international law does impose certain limits on the broad powers enjoyed by the states in that area, and that the manners in which states regulate matters bearing on nationality cannot today be deemed within their sole jurisdiction; those powers of the state are also circumscribed by their obligations to ensure the full protection of human rights.' Reiterated in case of the Yean and Bosico Children v. The Dominican Republic, Inter-American Court of Human Rights, Judgment of September 8, 2005, Series C No. 130, Para. 138.

11 Convention on Certain Questions Relating to the Conflict of Nationality Laws, 13 April 1930, League of Nations, Treaty Series, Vol. 179, No. 4137, p. 89. 
tional conventions, international custom, and the principles of law generally recognised with regard to nationality.

$[\ldots]$

Any question as to whether a person possesses the nationality of a particular State shall be determined in accordance with the law of that State.

In other words, how a State exercises its right to determine its nationals should conform to the relevant rules of international law, at least if such a nationality is meant to be accepted and considered as valid by other States. Violating those restrictions stemming from international law, which are aptly called 'negative international nationality law' by Paul Weis, ${ }^{12}$ will not invalidate the given nationality, but excludes its opposability against other States and prevents invoking it before international judicial fora as well as authorities of other States are entitled not to recognize it. ${ }^{13}$ We can conclude that the 1930 Hague Convention codified customary international law in this regard, ${ }^{14}$ and subsequent universal ${ }^{15}$ or regional ${ }^{16}$ conventions also follow this fundamental principle. Despite the fact that acquisition and loss of nationality are essentially governed by domestic legislation, today their regulation is of direct concern to the international legal order. ${ }^{17}$ 'The competence of States in this field may be exercised only within the limits set by international law' - opined the International Law Commission (ILC). ${ }^{18}$

Throughout the 20th century, the limitations deriving from international treaties, customary law and principles of law generally recognized with regard to nationality have been enriched mainly due to the gradual expansion of the international protection of human rights. This 'humanrightization' of international law triggered a paradigm shift also in this domain. As the Inter-American Court of Human Rights put it expressively, 'the classic doctrinal position, which viewed nationality as an attribute granted by the State

12 Weis, 1956, p. 92.

13 See also e.g. Dörr, 2012, Para. 4.

14 Weis, 1956, p. 65; C. Joseph, Nationality and Diplomatic Protection. The Commonwealth of Nations, A.W. Sijthoff, Leyden, 1969, p. 8; S. Hall, 'The European Convention on Nationality and the Right to Have Rights', European Law Review, December 1999, p. 589; M. Ganczer, Állampolgárság és államutódlás, Dialóg Campus, Budapest, 2013, p. 65.

15 Convention on the Nationality of Married Women of 20 February 1957 (UNTS No. 4468, Vol. 309, p. 65), entered into force on 11 August 1958.

161997 European Convention on Nationality (CETS No. 166). Its Art. 3 is almost identical with the definition contained in Art. 1 of the 1930 Hague Convention ('1. Each State shall determine under its own law who are its nationals. 2. This law shall be accepted by other States in so far as it is consistent with applicable international conventions, customary international law and the principles of law generally recognised with regard to nationality').

17 Human Rights and Arbitrary Deprivation of Nationality, Report of the Secretary-General. A/HRC/13/34, 14 December 2009, Para. 19.

18 Draft Articles on Nationality of Natural Persons in relation to the Succession of States with commentaries (Yearbook of the International Law Commission, 1999, Vol. II, Part 2, p. 24). 
to its subjects, has gradually evolved to a conception of nationality which, in addition to being the competence of the State, is a human right. ${ }^{39}$ In the same vein, the International Law Commission in its commentaries to the Draft Articles on the Nationality of Natural Persons in relation to Succession of States highlighted that the evolution of international human rights law has significantly altered the classical doctrine on the preponderance of States' interests over the interests of individuals. ${ }^{20}$

The prohibition of arbitrary deprivation of nationality counts as one of the above restrictions imposed by international human rights law. The right to a nationality as a core human right, ${ }^{21}$ as some denote: 'the right to have rights', ${ }^{22}$ implies the right of each individual to acquire, change and retain a nationality. The right to retain a nationality is intrinsically linked to the prohibition of arbitrary deprivation of nationality (the latter might be conceived as a precondition of the former, affording also protection to it). ${ }^{23}$ The explicit and implicit general prohibition of arbitrarily depriving someone's nationality, considered now as a rule of general customary international law, ${ }^{24}$ is found in numerous international instruments. The next part of the paper gives a tour d'horizon of such sources of law.

19 Proposed Amendments to the Naturalization Provision of the Constitution of Costa Rica, Inter-American Court of Human Rights, Advisory Opinion OC-4/84 of January 19, 1984. Series A No. 4, Para. 33.

20 Draft Articles on Nationality of Natural Persons in relation to the Succession of States with commentaries (Yearbook of the International Law Commission, 1999, Vol. II, Part 2, p. 24).

21 See first, the 1948 Universal Declaration of Human Rights (Art. 15 - right to a nationality); then a series of subsequent universal treaties: 1965 Convention on the Elimination of All Forms of Racial Discrimination (Art. 5 - non-discrimination; right to a nationality); the 1966 International Covenant on Civil and Political Rights (Art. 24 - right to acquire nationality); the 1979 Convention on the Elimination of All Forms of Discrimination against Women (Art. 9 - non-discrimination, re-acquisition, change, retention of nationality, nationality of children); the 1989 Convention on the Rights of the Child (Arts. 7 and 8 - birth registration, right to acquire nationality, avoidance of statelessness); the 2006 Convention on the Rights of Persons with Disabilities (Art. 18 - right to acquire and change a nationality) or other regional human rights treaties such as the 1969 American Convention on Human Rights; the 1990 African Charter on the Rights and Welfare of the Child; the 1995 Commonwealth of Independent States Convention on Human Rights and Fundamental Freedoms; or the 2004 Revised Arab Charter on Human Rights.

22 'Citizenship is man's basic right for it is nothing less than the right to have rights' (United States Supreme Court Chief Justice Earl Warren, in Trop v. Dulles, Secretary of State et al., 356 US 86, 1958; quoted e.g. in Independent Commission on International Humanitarian Issues, Winning the Human Race?, 1988, p. 107; M. Achiron, Nationality and Statelessness, A Handbook for Parliamentarians, Inter-Parliamentary Union United Nations High Commissioner for Refugees, Geneva, 2005, back cover; or L. van Waas, Nationality Matters: Statelessness under International Law, Intersentia, Antwerpen, 2008, p. 217.

23 Human rights and arbitrary deprivation of nationality, Report of the Secretary-General, A/HRC/13/34, 14 December 2009, Paras. 21, 26.

24 See e.g. Open Society Justice Initiative, 2005, pp. 2-3; M. Manly and L. van Waas, 'The Value of the Human Security Framework in Addressing Statelessness', in A. Edwards and C. Ferstman (Eds.), Human Security and Non-Citizens, Cambridge University Press, Cambridge, 2010, p. 63; Dörr, 2012, Para. 32; UN High Commissioner for Refugees, Expert Meeting - Interpreting the 1961 Statelessness Convention and Avoiding Statelessness resulting from Loss and Deprivation of Nationality ('Tunis Conclusions'), March 2014, Para. 2. In the Hungarian legal scholarship, e.g. A. Lörincz, 'Az állampolgársághoz való jog a nemzetközi jogban. A nemzeti szuverenitástól a mindenkit megillető emberi jogig’, 13 Romániai Magyar Jogtudományi Közlöny (2008), pp. 41-48. Nonetheless, some other authors are not convinced about its customary international law 


\subsection{The Evolution of the International Law Framework}

Starting with the universal level, the very first source of this cornerstone principle corollary to the right to a nationality is the 1948 Universal Declaration of Human Rights (UDHR). ${ }^{25}$ Its Article 15(2) contains the famous expression of the general rule: 'No one shall be arbitrarily deprived of his nationality nor denied the right to change his nationality'. Further United Nations (UN) human rights conventions incorporated this fundamental norm as well, either implicitly [e.g. 1957 Convention on the Nationality of Married Women, ${ }^{26} 1965$ Convention on the Elimination of All Forms of Racial Discrimination (CERD), ${ }^{27} 1979$ Convention on the Elimination of All Forms of Discrimination against Women (CEDAW), ${ }^{28}$ or 1989 Convention on the Rights of the Child (CRC $)^{29}$ ]; or, more recently, explicitly [2006 Convention on Rights of Persons with Disabilities (CRPD) ${ }^{30}$. This general legal framework on the international protection of human rights is complemented by a specific instrument,

character, arguing that "the only limit imposed by customary international law on States' powers to withdraw nationality is the one banning measures of denaturalization based solely on racial or religious reasons since such acts would infringe the customary law rule on non-discrimination on grounds of race and religion." (R. Hofmann, 'Denaturalization and Forced Exile', in W. Rüdiger (Ed.), The Max Planck Encyclopedia of Public International Law, Oxford, University Press, 2013, Para. 17).

25 Universal Declaration of Human Rights, adopted by General Assembly Resolution 217 A(III) of 10 December 1948. The UDHR is available in 369 language variations on the website of the Office of the United Nations High Commissioner for Human Rights.

26 Convention on the Nationality of Married Women of 20 February 1957 (UNTS No. 4468, Vol. 309, p. 65), entered into force on 11 August 1958. Arts. 1-2: 'Each Contracting State agrees that neither the celebration nor the dissolution of a marriage between one of its nationals and an alien, nor the change of nationality by the husband during marriage, shall automatically affect the nationality of the wife. [...] Each Contracting State agrees that neither the voluntary acquisition of the nationality of another State nor the renunciation of its nationality by one of its nationals shall prevent the retention of its nationality by the wife of such national.'

27 International Convention on the Elimination of All Forms of Racial Discrimination of 21 December 1965 (UNTS No. 9464, Vol. 660, p. 195), entered into force on 4 January 1969. Art. 5 lit. (d) (iii): ‘[... States Parties undertake to prohibit and to eliminate racial discrimination in all its forms and to guarantee the right of everyone, without distinction as to race, colour, or national or ethnic origin, to equality before the law, notably in the enjoyment of the following rights: [...] (d) Other civil rights, in particular: [...] The right to nationality.'

28 Convention on the Elimination of All Forms of Discrimination against Women of 18 December 1979 (UNTS No. 20378, Vol. 1249, p. 13), entered into force on 3 September 1981. Art. 9(1): ' [...] neither marriage to an alien nor change of nationality by the husband during marriage shall automatically change the nationality of the wife, render her stateless [...].'

29 Convention on the Rights of the Child of 20 November 1989 (UNTS No. 27531, Vol. 1577, p. 3), entered into force on 2 September 1990. Art. 8(1): 'States Parties undertake to respect the right of the child to preserve his or her identity, including nationality [...] without unlawful interference.'

30 Convention on the Rights of Persons with Disabilities of 13 December 2006 (UNTS No. 44910, Vol. 2515, p. 3), entered into force on 3 May 2008. Art. 18(1) lit. (a) expressly stipulates: '1. States Parties shall recognize the rights of persons with disabilities to liberty of movement, to freedom to choose their residence and to a nationality, on an equal basis with others, including by ensuring that persons with disabilities: [...] (a) Have the right to acquire and change a nationality and are not deprived of their nationality arbitrarily or on the basis of disability.' 
the 1961 UN Convention on the Reduction of Statelessness (CRS), ${ }^{31}$ which deals specifically with the prohibition of arbitrary deprivation of nationality in the context of statelessness. In particular, Article 8(1) of the 1961 Convention enshrines this ban by stating that 'Contracting States shall not deprive a person of his nationality if such deprivation would render him stateless'.

If we turn our attention to de lege ferenda proposals of universal character, the same obligation is reconfirmed in different contexts. First, the ILC's Draft Articles on the nationality of natural persons in relation to state succession (1999) lays down the prohibition of arbitrary decisions concerning nationality, including not to be arbitrarily deprived of the nationality of the predecessor State when state succession occurs (Article 16). ${ }^{32}$ Thereafter, the ILC aimed at regulating another aspect of this harsh human rights violation, outlawing the deprivation of nationality for the sole purpose of expulsion in the Draft Articles on the expulsion of aliens, adopted in second reading in August 2014 (Article 8). ${ }^{33}$ Its Commentaries make it clear why: such a deprivation of nationality, insofar as it has no other justification than the State's desire to expel the individual, would be abusive, indeed arbitrary within the meaning of Article 15(2) UDHR. ${ }^{34}$ An interesting question arises here, namely whether the above principles of law enshrined in the Draft Articles have already or will in the near future attain the status of customary international law, elaborating further the content of the generally accepted prohibition of arbitrary deprivation of nationality.

In addition, a massive body of soft law has been developed echoing the above hard law obligations, such as UN General Assembly resolutions adopted since the mid-'90s, ${ }^{35}$ burgeoning resolutions of the former UN Commission on Human Rights ${ }^{36}$ and the Human Rights Council, ${ }^{37}$ general comments and recommendations of different treaty bodies, ${ }^{38}$ as

31 Convention on the Reduction of Statelessness of August 30, 1961 (UNTS No. 14458, Vol. 989, p. 175), entered into force on 13 December 1975.

32 Draft Articles on Nationality of Natural Persons in relation to the Succession of States with commentaries (1999), p. 37.

33 Report of the International Law Commission, Sixty-sixth session (5 May-6 June and 7 July-8 August 2014), General Assembly Official Records, Sixty-ninth session, Supplement No. 10, A/69/10, Chapter IV, p. 33.

34 Ibid.

35 UNGA Resolution 50/152 of 21 December 1995. Office of the United Nations High Commissioner for Refugees (A/RES/50/152), Para. 16; UNGA Resolution 54/146 of 17 December 1999. Office of the United Nations High Commissioner for Refugees (A/RES/54/146), Para 22.

36 E.g. Resolution on Human Rights and Arbitrary Deprivation of Nationality, 1997/36, 11 April 1997; Resolution on Human Rights and Arbitrary Deprivation of Nationality, 2005/45, 19 April 2005.

37 E.g. UN Human Rights Council Resolutions 7/10 of 27 March 2008 (A/HRC/RES/7/10); 10/13 of 26 March 2009 (A/HRC/RES/10/13); 13/2 of 24 March 2010 (A/HRC/RES/13/2); 20/5 of 16 July 2012 (A/HRC/RES/20/5).

38 See for instance UN Human Rights Committee, CCPR General Comment No. 27: Article 12 (Freedom of Movement), 2 November 1999, CCPR/C/21/Rev.1/Add.9; UN Committee on the Elimination of Racial Discrimination, CERD General Recommendation XXX on Discrimination Against Non Citizens, 1 October 2002; or UN Committee on the Elimination of Discrimination Against Women, CEDAW General Recommendation No. 21: Equality in Marriage and Family Relations, 1994, CEDAW/C/1995/7, Annex, Appendix, chapter III 
well as a series of conclusions adopted by the Executive Committee of the High Commissioner's Programme, United Nations High Commissioner for Refugees (UNHCR ExCom). ${ }^{39}$

Examining the regional level of the international law framework, the regional structures in almost every continent devote specific attention to this matter of fundamental importance. Starting with Europe, the most important instrument is the 1997 European Convention on Nationality (ECN), which repeats the general prohibition set forth in the UDHR: 'no one should be arbitrarily deprived of his or her nationality. ${ }^{40}$ This is accompanied by soft law documents emanating either from the Committee of Ministers or the Parliamentary Assembly of the Council of Europe, among which the best known is Recommendation No. R (1999) 18 of the Committee of Ministers on the avoidance and the reduction of statelessness (1999) laying down further requirements in order to limit deprivation of nationality and mitigate its negative effects. ${ }^{41}$ Numerous other regional human rights conventions incorporated a very similar provision (the 1969 American Convention on Human Rights, ${ }^{42}$ the 1995 Commonwealth of Independent States Convention on Human Rights and Fundamental Freedoms, ${ }^{43}$ and the 2004 Revised Arab Charter on Human Rights $^{44}$ ). Interestingly, in the 2004 Revised Arab Charter on Human Rights it is not 'arbitrary' deprivation which is forbidden but if someone's nationality is deprived 'without a legally valid reason.'

Summing up the above, the prohibition of arbitrary deprivation of nationality is now a well-established customary norm of international law, declared by a complex set of international instruments, on different levels of regulation. Given that this general prohibition represents the negative aspect of the right to a nationality, it is submitted that under international law as it stands today, the prohibition of arbitrary deprivation of nationality qualifies as a fundamental human right as well, protecting the individual from the unjustified and drastic interference into his/her identity by the State of nationality.

B. These general comments and recommendations may be conceived as the authentic interpretation of the respective conventions.

39 UNHCR ExCom conclusions No. 65 (XLII) 1991; No. 78 (XLVI) 1995; No. 102 (LVI) 2005; and No. 106 (LVI) 2006 (available at: www.unhcr.org/41b4607c4.pdf, last accessed on 1 July 2014).

40 Art. 4 lit. c.

41 Point I c., point II. C. c.

42 Art. 20(3): 'No one shall be arbitrarily deprived of his nationality or of the right to change it.'

43 Art. 24(2): 'No one shall be arbitrarily deprived of his citizenship or of the right to change it.'

44 Art. 29(1): 'Every person has the right to a nationality, and no citizen shall be deprived of his nationality without a legally valid reason.' 


\subsection{Meaning and Content of the 'Prohibition of Arbitrary Deprivation of Nationality'}

Before going into the in-depth analysis of the meaning of the 'prohibition of arbitrary deprivation of nationality' as well as exploring its content, it is first necessary to define the notion of 'deprivation of nationality'. 'Deprivation' as such always means an act without the request/consent of the person concerned. While deprivation of nationality does not comprise loss of nationality voluntarily requested by the individual concerned (renunciation), it comprises all other forms of involuntary loss of nationality (in other words: denaturalization ${ }^{45}$ or denationalization). ${ }^{46}$ Resolutions of the UN Human Rights Council clearly established that the term 'deprivation' in the UDHR includes both arbitrary ex lege loss (when denaturalization occurs automatically by operation of law) and individual acts of deprivation taken by administrative or judicial authorities. ${ }^{47} \mathrm{~A}$ different approach is taken by the 1961 UN Convention on the Reduction of Statelessness. The Convention makes an explicit distinction when using both terms: 'loss of nationality' describes withdrawal of nationality which is automatic, ex lege (Articles 5-7), and the term 'deprivation' denotes situations where the withdrawal of nationality is initiated by the authorities of the State (Article 8). According to UNHCR, the category of 'withdrawal of nationality' in the broad sense refers to both loss and deprivation of nationality. ${ }^{48}$ Against this backdrop, I understand 'deprivation' in the broader meaning of the word, therefore, in this paper 'deprivation of nationality' is interchangeable with 'withdrawal of nationality' or 'involuntary loss of nationality'. It covers all forms of denaturalization made by the State, such as automatically depriving a person or a group of people (en masse) of a nationality by operation of law (e.g. Slovakia's nationality law sanctioning acquisition of another nationality by deprivation of Slovak nationality); arbitrarily precluding a person from retaining a nationality, particularly on discriminatory grounds; individual acts taken by administrative or judicial authorities withdrawing someone's nationality ${ }^{49}$; or even situations where there is no formal act of State but the practice of the competent authorities shows with no doubt that they have ceased to consider a particular individual or group of people

45 For the use of this term, see e.g. Hofmann, 2013, Para. 1.

46 Arbitrary deprivation of nationality: report of the Secretary-General. A/HRC/10/34, 26 January 2009, Para. 49; Human Rights and Arbitrary Deprivation of Nationality, Report of the Secretary-General. A/HRC/13/34, 14 December 2009, Para. 23; in the legal literature van Waas, 2008, p. 34; and implicitly Dörr, 2012, Para. 35.

47 R. de Groot, 'Survey on Rules on Loss of Nationality in International Treaties and Case Law', CEPS Paper in Liberty and Security in Europe, No. 57/August 2013, p. 1; UNHCR, 'Tunis Conclusions', Para. 9.

48 Ibid., Para. 9.

49 Human Rights and Arbitrary Deprivation of Nationality, Report of the Secretary-General. A/HRC/13/34, 14 December 2009, Para. 23. 
as national(s) (e.g. failure to issue or renew identity documents without any explanation, confiscation or destruction of identity documents). ${ }^{50}$

At the very outset, it shall be stressed that there is no absolute ban under international law regarding deprivation of nationality. Denaturalization is permitted under certain conditions, thus, States still possess a certain freedom to act in withdrawing one's nationality. However, if an act of deprivation is arbitrary, it per se violates international law. What exactly amounts to 'arbitrary' deprivation of nationality is unclear, since neither the UDHR, nor the relevant universal or regional treaties on human rights elaborate on this issue. Other sources of law and legal scholarship should thus be considered thoroughly so as to find legally tenable answers. Below, I shall analyse and outline the main forms and scenarios of arbitrary deprivation of nationality which are by definition forbidden.

\subsubsection{Deprivation of Nationality against the Law: Arbitrary}

First of all, in light of the requirements stemming from the rule of law, deprivation of nationality must have a firm legal basis in national law, as a precondition to making this harsh intervention into a person's life predictable. In other words, in order to avoid an allegation of arbitrariness, nationality may, first and foremost, only be deprived as prescribed by law. ${ }^{51}$ It is widely recognized that legal provisions relating to the withdrawal of nationality may neither be based on analogia iuris or legis, nor be enacted or applied with retroactivity. ${ }^{52}$ Furthermore, when interpreting the ordinary meaning ${ }^{53}$ of 'arbitrariness', this term is not to be equated merely with 'against the law', but rather a broader meaning should be afforded to it, encompassing also an abuse of power that is indeed achieved through the law. By virtue of the general comments of the Human Rights Committee (HRC) of the 1966 International Covenant on Civil and Political Rights (ICCPR), the expression 'arbitrary interference' could also extend to interference provided for by domestic law. ${ }^{54}$ In the HRC's view, the introduction of the concept of arbitrariness was intended to guarantee that even formally lawful interference, in conformity with domestic law, shall be in accordance with the provisions, aims and objectives of the ICCPR, and

50 UNHCR, 'Tunis Conclusions', Para 11.

51 van Waas, 2008, p. 94.

52 Ibid., Para. 16.

53 See Art. 31(1) of the 1969 Vienna Convention on the Law of the Treaties (UNTS No. 18232, Vol. 1155, p. 331), entered into force on 27 January 1980.

54 UN Human Rights Committee, CCPR General Comment No. 16: Art. 17 (Right to Privacy), The Right to Respect of Privacy, Family, Home and Correspondence, and Protection of Honour and Reputation, 8 April 1988, Para. 4; UN Human Rights Committee, CCPR General Comment No. 27: Article 12 (Freedom of Movement), 2 November 1999, CCPR/C/21/Rev.1/Add., Para. 21. 
should always be reasonable given the particular circumstances. ${ }^{55}$ As a consequence, the concept of 'arbitrariness' includes, beyond the 'unlawful', also the elements of inappropriateness, injustice, illegitimacy or lack of predictability. ${ }^{56}$ This broad concept is necessary, otherwise an interpretation of arbitrary deprivation as amounting only to illegal deprivation would make it far too easy for States to circumvent the aim of this prohibition (i.e. to effectively protect individuals). ${ }^{57}$ The HRC further indicated that the notion of arbitrariness applies to the action of all State organs (legislative, administrative/executive or judicial). ${ }^{58}$

\subsubsection{Deprivation of Nationality in Violation of Procedural Standards: Arbitrary}

In the preceding point I examined the most basic formality to be met for a decision not to be deemed arbitrary, i.e. that such a decision of deprivation must conform to the law in force. As Laura van Waas puts it: 'This is an important criterion because it helps to ensure that the decisions of the authority are foreseeable. ${ }^{59}$ Besides this requirement of being in conformity with domestic law, there are other procedural standards, developed mainly by international human rights law, which must be met. Procedural safeguards are essential to prevent abuses in the process of the application of law. States are thus expected to observe minimum procedural standards in order to ensure that decisions withdrawing a nationality do not contain any element of arbitrariness. ${ }^{60}$ First, measures leading to deprivation of nationality must serve a legitimate purpose that is consistent with international law, in particular with the objectives of international human rights law. Such measures must be the least intrusive instrument amongst those which might achieve the desired result, applied as a measure of last resort (ultima ratio) and they must be proportional to the interest to be protected. ${ }^{61}$ Moreover, other specific procedural guarantees also apply: any decision on

55 This interpretation is supported by the travaux préparatoires of the provision on the prohibition of arbitrary deprivation of nationality in the UDHR [Art. 15(2)]. See N. Robinson, The Universal Declaration of Human Rights. Its Origin, Significance, Application and Interpretation, Institute of Jewish Affairs, New York., 1958; or A. Verdoodt, Naissance et Signification de la Déclaration Universelle des Droits de l'Homme, E. Warny, Louvain, 1964 (both sources quoted by van Waas, 2008, p. 94).

56 Similarly see: UN Human Rights Committee, A. v. Australia, Communication No. 560/1993: Australia, 9.2; CCPR/C/59/D/560/1993 (April 30, 1997).

57 S. Mantu, Deprivation of Citizenship from the Perspective of International and European Legal Standards, ENACT Consortium, FP7-SSH-2007-1-217504-ENACT/D4.2, p. 10.

58 See also: Human Rights and Arbitrary Deprivation of Nationality, Report of the Secretary-General. A/HRC/13/34, 14 December 2009, Paras. 49-50.

59 van Waas, 2008, p. 113.

60 Human Rights and Arbitrary Deprivation of Nationality, Report of the Secretary-General. A/HRC/13/34, 14 December 2009, Para. 43.

61 Arbitrary deprivation of nationality: report of the Secretary-General. A/HRC/10/34, 26 January 2009, Para. 49; Human Rights and Arbitrary Deprivation of Nationality, Report of the Secretary-General. A/HRC/13/34, 14 December 2009, Para. 25. 
deprivation of nationality shall be issued with reasons stated in writing and shall be subject to legal review by a court or an independent body (as prescribed by the 1961 Convention on the Reduction of Statelessness ${ }^{62}$ and on the regional level, by the 1997 European Convention on Nationality ${ }^{63}$ ). The right to legal (judicial) remedies provides an opportunity for overturning unlawful, unreasonable or discriminatory decisions on denaturalization and stands as a cornerstone of due process of law. ${ }^{64}$ These procedural safeguards have been later reaffirmed by the International Law Commission as well, in the context of state succession. The commentaries to the Draft Articles on Nationality of Natural Persons in relation to the Succession of States elaborated more on this: ' $\mathrm{t}$ ] he requirement of giving reasons for any negative decisions concerning nationality should be considered as one of the prerequisites of an effective administrative or judicial review' and concluded that the above procedural elements represent minimum requirements in this respect. The ILC also clarified that the adjective 'effective' requires that an opportunity has to be provided to permit meaningful review of the relevant substantive issues (in the same sense as expressed by the ICCPR). ${ }^{65}$ As a consequence, decisions depriving someone's nationality, which are formally in accordance with law, but falling short of these procedural standards and safeguards, are to be considered arbitrary under general international law.

62 Art. 8(4) stipulates: 'A Contracting State shall not exercise a power of deprivation permitted by [...] this Article except in accordance with law, which shall provide for the person concerned the right to a fair hearing by a court or other independent body.'

63 Art. 11 sets forth that 'Each State Party shall ensure that decisions relating to the [...] loss [...] of its nationality contain reasons in writing.' Then Art. 12 continues as follows: 'Each State Party shall ensure that decisions relating to the [...] loss [...] of its nationality be open to an administrative or judicial review in conformity with its internal law.' However, this obligation is weakened by possible reservations made to these Articles, allowed by the Convention [see Art. 29(1)] and some Council of Europe Member States actually made use of this option (e.g. Bulgaria, Denmark or Hungary in relation to Art. 12 - see: http://conventions.coe.int, last accessed on 1 July 2014). For a detailed analysis on the reservations and declarations with respect to the Convention, see: L. Pilgram, European Convention on Nationality (ECN) 1997 and European Nationality Laws, EUDO CITIZENSHIP Policy Brief No. 4.

64 Despite the availability of legal avenues to challenge decisions on deprivation of nationality, judicial review might reach flowed results, in contravention of international law, as shown by recent cases in the United Kingdom (see e.g. B2 v., The Secretary of State for the Home Department, Judgment of 24 May 2013 [2013] EWCA Civ 616). To the contrary, the Supreme Court delivered victory against arbitrary deprivation of nationality resulting in statelessness in the Al-Jedda case in October 2013 (Secretary of State for the Home Department (Appellant) v. Al-Jedda (Respondent), Judgment of 9 October 2013 [2013] UKSC 62, available at: www.opensocietyfoundations.org/sites/default/files/domestic-al-jedda-judgment-20131009.pdf (accessed on 1 July 2014). For a recent analysis of UK administrative and judicial practice on deprivation of nationality, see: S. Mantu, 'Citizenship Deprivation in the United Kingdom. Statelessness and Terrorism', 19 Tilburg Law Review 2014, pp. 163-170.

65 Draft Articles on Nationality of Natural Persons in relation to the Succession of States with commentaries (Yearbook of the International Law Commission, 1999, Vol. II, Part 2, p. 38). 


\subsubsection{Deprivation of Nationality on Discriminatory Grounds: Arbitrary}

The prohibition of arbitrary denaturalization, aiming at protecting the right to retain a nationality, is implicitly enshrined in human rights conventions that spell out specific forms of discrimination. As a result, deprivation of nationality may not be based on discrimination on any grounds prohibited under international human rights law, either in law or in practice. ${ }^{66}$ Going through these treaty law sources chronologically, already the 1961 Convention on the Reduction on Statelessness outlawed discrimination in the context of deprivation of nationality specifically on racial, ethnic, religious, or political grounds (Article 9). ${ }^{67}$ This is the only provision in the Convention not directly focused on the prevention of statelessness: it is irrelevant whether such deprivation leads to statelessness or not, it is an outright prohibition and such an act of the State is unlawful under the Convention. Article 5 lit.(d)(iii) of the 1965 CERD prohibited racial discrimination in respect of the right to nationality, and the Committee on the Elimination of Racial Discrimination shed more light on this obligation highlighting that States should 'recognize that deprivation of citizenship on the basis of race, colour, descent, or national or ethnic origin is a breach of States parties' obligations to ensure non-discriminatory enjoyment of the right to nationality, ${ }^{68}$ which obligation qualifies as a peremptory norm of international law (ius cogens). While the 1979 CEDAW does not incorporate a specific prohibition in this regard (although it recognizes women's right to retain their nationality regardless of the celebration or dissolution of a marriage or the change of nationality by a husband), ${ }^{69}$ later on, the Committee on the Elimination of Discrimination against Women also made it explicit that 'nationality [...] should not be arbitrarily removed because of marriage of dissolution of marriage or because her husband or father changes his nationality. ${ }^{, 70}$ Finally, the 2006 $C R P D$ is the only core UN human rights convention which explicitly addresses the prohibition of denationalization on the grounds of disability. ${ }^{71}$ In addition to these 'hard law' stipulations, resolutions on nationality of the UN Human Rights Council have also set out a broad range of prohibited discriminatory grounds (such as race, colour, sex, language,

66 UNHCR, 'Tunis Conclusions', Para. 18.

67 Art. 9 states: 'A Contracting State may not deprive any person or group of persons of their nationality on racial, ethnic, religious or political grounds.' This provision was historically designed to give effect to Art. 15(2) of the UDHR.

68 UN Committee on the Elimination of Racial Discrimination, CERD General Recommendation XXX on Discrimination Against Non Citizens, 1 October 2002, Para. 14.

69 Art. 9.

70 UN Committee on the Elimination of Discrimination Against Women, CEDAW General Recommendation No. 21: Equality in Marriage and Family Relations, 1994, Para. 6. (CEDAW/C/1995/7, Annex, Appendix, chapter III B).

71 Art. 18(1) lit. (a): 'States Parties shall recognize the rights of persons with disabilities [...] to a nationality, on an equal basis with others, including by ensuring that persons with disabilities: [...] (a) [...] are not deprived of their nationality arbitrarily or on the basis of disability.' 
religion, political or other opinion, national or social origin, property, birth or other status, etc.). ${ }^{72}$ It can therefore be argued that the prohibited grounds for discrimination in cases of the withdrawal of nationality include all the grounds enshrined in Article 2 of the ICCPR. According to leading legal scholars, the non-discrimination principle regarding nationality constitutes a rule of customary international law, ${ }^{73}$ therefore, it provides a far reaching and effective legal safety net against arbitrary deprivation.

\subsubsection{Deprivation of Nationality Resulting in Statelessness: Arbitrary}

The avoidance of statelessness is a general principle of today's international law. Statelessness is undesirable not only from the viewpoint of the individual, but also from the states (e.g. in light of issues of human security) ${ }^{74}$ Deprivation of nationality leads to statelessness where the person concerned does not possess or immediately acquire another nationality. ${ }^{75}$ Historically, the first major, internationally recognized statelessness situations have been created by mass denationalisation policies following World War I and in the period preceding World War II. ${ }^{76}$ Pursuant to the academic communis opinio in this matter, deprivation of nationality resulting in statelessness would generally be arbitrary, ${ }^{77}$ unless it serves a legitimate purpose and complies with the principle of proportionality. This approach is clearly underpinned by different universal and regional treaty provisions. The point of departure is again the 1961 CRS. Its Article 8(1) lays down the general rule: '[a] Contracting State shall not deprive a person of its nationality if such deprivation would render him stateless.'

Nevertheless, there exists an exhaustive list of exceptions under this obligation: the subsequent paragraphs of the same Article allow for a limited set of circumstances under which deprivation of nationality resulting in statelessness is still permitted. In line with the general principle of interpretation in international human rights law, confirmed by

72 See e.g. UN Human Rights Council Resolutions 7/10 of 27 March 2008 (A/HRC/RES/7/10), operative Paras. 2-3; 10/13 of 26 March 2009 (A/HRC/RES/10/13), operative Paras. 2-3; or 20/5 of 16 July 2012 (A/HRC/RES/20/5), operative Paras. 2 and 4.

73 E.g. Dörr, 2012, Para. 6.

74 Manly and van Waas, 2010, pp. 63-66; Dörr, 2012, Para. 9.

75 Arbitrary deprivation of nationality: report of the Secretary-General. A/HRC/10/34, 26 January 2009, Para. 51.

76 For concrete historical examples, see e.g. Hofmann, 2013, Paras. 4-8.

77 E.g. J. Chan, 'The Right to a Nationality as a Human Right - The Current Trend Towards Recognition', 12 Human Rights Law Journal (1991), pp. 1-14; R. Donner, The Regulation of Nationality in International Law, Transnational Publishers, New York, 1994 (Chapter 4: Human Rights Conventions and Other Instruments); J. Goldston, 'Holes in the Rights Framework: Racial Discrimination, Citizenship, and the Rights of Noncitizens', 20 Ethics and International Affairs (2006), pp. 321-347 (all quoted by L. van Waas, 2008, p. 40); Fourth report on the expulsion of aliens by Mr. Maurice Kamto, Special Rapporteur, International Law Commission, 60th session, A/CN.4/594, 24 March 2008, Para. 29. 
the intention of the drafters of the 1961 CRS articulated in the travaux préparatoires, ${ }^{78}$ these narrowly construed exceptions under the general rule shall be interpreted in a restrictive manner. First, naturalized persons may be rendered stateless by withdrawal of nationality if they have resided abroad for at least seven years and failed to declare their intention to retain their nationality [Article 8(2) lit. (a)]. Second, by virtue of the same provision, States may also deprive persons born abroad of their nationality if one year after attaining majority, they do not reside in the State of nationality or register with the appropriate authority. Third, deprivation of nationality rendering someone stateless is also permissible if the nationality has been obtained by misrepresentation or fraud [Article 8 (2) lit. (b) $].{ }^{79}$ In relation to the latter, it is to be noted that there must be causality between the fraud or misrepresentation and the grant of nationality. This means that the fraud must be material to the acquisition of nationality. Furthermore, deprivation based on misrepresentation or fraud would not be justified if the person was not aware and could not have been aware that the information provided during the naturalization was untrue. ${ }^{80}$ In addition, a specific situation is worth examining: when authorities are considering the deprivation of nationality of children due to misrepresentation or fraud. Here, one may ask whether the main objective of preventing statelessness of children laid down in both the 1961 Convention (Articles 1-4) and the 1989 CRC (Articles 7-8), read in light of the principle of the best interest of the child, could prevail over this exception? ${ }^{81}$ It is easy to argue that rendering a minor stateless is never in his/her best interest. As a consequence, I find it legally tenable to conclude that thanks to the development of international human rights law in the last decades, deprivation of children's nationality on the basis of misrepresentation and fraud is now outlawed if it results in statelessness, owing to the considerations of the best interest of the child and the principle of proportionality which plays the most significant role here amongst the exceptions set out in Article 8(2) of the 1961 CRS. Finally, certain additional exceptions are provided for in Article 8(3), which is a 'stand still clause': they can be applied only in so far as those grounds have already been envisaged in the domestic law of the Contracting State at the time of signature, ratification or accession and the State expressly indicates its intention to retain them when it gives its consent to be bound by the Convention. Only 15\% of the Contracting States have made use of this provision to retain a specific ground for deprivation of nationality under the stand still clause. $^{82}$ The exceptions cover two types of situations. They allow for deprivation of

78 Under the 1969 Vienna Convention on the Law of the Treaties (VCLT), travaux préparatoires can be used as a supplementary means of treaty interpretation (Art. 32).

79 For a comprehensive analysis of this provisions and their desired interpretation, see UNHCR, 'Tunis Conclusions', Paras. 52-64.

80 UNHCR, 'Tunis Conclusions', Paras. 58-59.

81 See similarly: ibid., Para. 62.

82 Ibid., Para. 65. The list of such declarations can be consulted at https://treaties.un.org/doc/Publication/ MTDSG/Volume\%20I/Chapter\%20V/V-4.en.pdf (last accessed on 1 July 2014). 
nationality resulting in statelessness due to 1) conduct inconsistent with the duty of loyalty to the State (on the basis of services rendered or emoluments received from foreign States, ${ }^{83}$ or on the basis of a conduct seriously prejudicial to the vital interest of the State ${ }^{84}$ ) or 2) because of evidence of allegiance to another State (the person has taken an oath, or made a formal declaration of allegiance to another State). As Mantu explains: ' $t$ ] hese exceptions are related to the main duty that citizens have towards their state, namely the duty of loyalty. Thus when that duty is breached the state has the power to sever the formal link between itself and the citizen, and deny him membership as punishment for his acts. ${ }^{85}$ However, the last exception (allegiance to another State) seems to be obsolete in most circumstances, since usually the only opportunity for a person to make a formal oath of allegiance to another State is at the very last phase of the naturalization procedure, when the occurrence of statelessness is no longer an issue. Moreover, I share the view that this scenario has also been superseded by later developments in domestic nationality laws which increasingly place less importance on formal allegiance to the State. ${ }^{86}$

The above regulatory architecture clearly shows that international law leaves just a thin margin of manoeuvre for States when they wish to lawfully withdraw a person's nationality causing statelessness. Article 8(1)-(3) of the 1961 CRS aim at striking a delicate balance between the rights of the individual and the legitimate interests of the State. The underlying concept is that deprivation of nationality resulting in statelessness is generally arbitrary, since its impact on the individual outweighs by far the interests the State seeks to protect. This approach is also evidenced by the fact that the Convention does not allow reservations to these provisions ${ }^{87}$ or for States to otherwise exclude individuals from the scope of the Convention due to other types of conduct (exhaustive list of exceptions). ${ }^{88}$ What is more, the procedural due process requirement is explicit in this context: in all cases of permitted deprivation of nationality, such a decision may only be made in accordance with law, and

83 Art. 8(3) lit. (a)(i). As highlighted by UNHCR, this exception must be interpreted narrowly and may not be applied where the individual rendered services to, or received emoluments from an entity which does not constitute a State (e.g. an intergovernmental organization, a non-State actor in an armed conflict, or an NGO). See ibid., Para. 67.

84 Art. 8(3) lit. (a)(ii). This exception to the basic rule established a very high threshold for deprivation of nationality resulting in statelessness. Taking the ordinary meaning of the terms 'seriously prejudicial' and 'vital interest', in accordance with Art. 31(1) of 1969 VCLT, such a conduct must threaten the very foundations and internal structure of that State whose nationality is at stake. The notion 'seriously prejudicial' requires that the individual concerned is actually capable of negatively impacting the State. Similarly, 'vital interest' sets a much higher threshold than 'national interest' which is confirmed by the travaux préparatoires. See: ibid., Para. 68.

85 Mantu, 2009, p. 9.

86 UNHCR, 'Tunis Conclusions', Para. 69.

87 Art. 17 of the 1961 CRS stipulates:

' 1 . At the time of signature, ratification or accession any State may make a reservation in respect of Arts. 11, 14 or 15.

2. No other reservations to this Convention shall be admissible.'

UNHCR, 'Tunis Conclusions', Para. 23. 
against it the right to a fair hearing by a court or other independent body shall be provided for [Article 8(4)].

If we turn our attention to the regional level, we may witness an even stronger protection against arbitrary deprivation of nationality resulting in statelessness. The 1997 European Convention on Nationality, placing the prohibition of arbitrarily depriving one of his/her nationality amongst the basic principles upon which 'rules on nationality of each State Party shall be based', ${ }^{89}$ went further by setting out more limited restrictions on the possible exceptions. ${ }^{90}$ Its Article 7(3) allows for deprivation of nationality resulting in statelessness only and exclusively in cases of misrepresentation and fraud (according to the Convention language: 'by means of fraudulent conduct, false information or concealment of any relevant fact attributable to the applicant'). ${ }^{91}$ The old-fashioned exceptions introduced by Article 8(2)-(3) of the 1961 CRS have not been taken up by the drafters of the European Convention. The Explanatory Report of the ECN, which is an official means for interpreting the Convention by virtue of Article 31(3) of the 1969 VCLT, ${ }^{92}$ goes into the details concerning the conditions of the application of the 'misrepresentation and fraud' exception by saying that fraudulent conduct, false information or concealment of any relevant fact has to be the result of a deliberate act or omission by the applicant which was a significant factor in the acquisition of nationality. Moreover, 'concealment of any relevant fact' means concealment of a relevant condition which would prevent the acquisition of nationality by the person concerned (such as bigamy). Finally, it explains that 'relevant' in this context refers to facts (such as concealment of another nationality, or concealment of a criminal conviction for a serious offence) which, if they had been known before the nationality was granted, would have resulted in a decision refusing to grant such nationality. ${ }^{93}$ Even within the boundaries of this exception, Recommendation No. R (1999) 18 aims at narrowing State discretion by commending a balancing approach and factors to be considered before such a decision is taken: '[i]n order to avoid situations of statelessness, a State should not necessarily deprive of its nationality persons who have acquired its nationality by fraudulent conduct, false information or concealment of any relevant fact. To this effect, the gravity of the facts as well as other relevant circumstances, such as the genuine and effective link of these persons with the State concerned, should be taken into account. ${ }^{94}$ This soft law

89 Art. 4. lit. c.

90 See also: Explanatory Report to the European Convention on Nationality (ETS No. 166), Para. 77. (available at http://conventions.coe.int/Treaty/en/Reports/Html/166.htm (last accessed on 1 July 2014).

91 Art. 7(1) lit. b.

92 Art. 31(2) lit. b): 'The context for the purpose of the interpretation of a treaty shall comprise [...] (b) any instrument which was made by one or more parties in connection with the conclusion of the treaty and accepted by the other parties as an instrument related to the treaty' [emphasis added - M.T.].

93 Explanatory Report to the European Convention on Nationality (ETS No. 166), Para. 61. In the Hungarian legal scholarship also mentioned e.g. by A. Lőrincz, 'Az állampolgárságtól való megfosztás mint biztonsági eszköz’, XIII Pécsi Határör Tudományos Közlemények (2012), pp. 323-324.

94 Principle II. C. c. (emphasis added). 
norm therefore emphasizes the importance of narrowly construing an exception of this kind as well as of the principle of proportionality. ${ }^{95}$

\subsubsection{Deprivation of Nationality for the Sole Purpose of Expulsion: Arbitrary}

When arbitrary withdrawal of nationality is combined with expulsion from the territory of the State of former nationality, the violation of international law becomes even more flagrant. As the UNHCR observes, discriminatory denationalization of individuals is often followed by their expulsion. ${ }^{96}$ In history, there have been a number of instances when States have resorted to the practice of depriving persons of their nationality in order to circumvent the rule that a State could not expel its nationals. ${ }^{97}$ This issue has recently come up in the jurisprudence of the Ethiopia-Eritrea Claims Commission with regard to dual (Ethiopian-Eritrean) nationals. ${ }^{98}$ Although the Claims Commission in its award rejected Eritrea's argument that the denationalization and subsequent expulsion of persons with dual Ethiopian and Eritrean nationality were contrary to international law, the Commission held that the expulsion from Ethiopia of dual nationals for unknown security reasons, was arbitrary and thus contrary to international law. ${ }^{99}$ The International Law Commission also devoted attention to this situation when preparing the Draft Articles on the expulsion of aliens, adopted in second reading in August 2014. Article 8 of this text states that a 'state shall not make its national an alien, by deprivation of nationality, for the sole purpose of expelling him or her'. In the ILC's view, such a deprivation of nationality, irrespective of the fact that it is the person's sole nationality or he is a dual national, would be abusive, indeed arbitrary. ${ }^{100}$ What is apparent is that this rule is without any doubt applicable for dual (multiple) nationals. On the other hand, when such an abusive denationalization causes statelessness, it is ab ovo considered arbitrary save the legitimate exceptions established by the 1961 CRS generally or the 1997 ECN specifically, on the European continent. However, the scenario envisaged in Draft Article 8 can be conceived as a complementary means of protection against such an arbitrary act of the State. Even if a decision on deprivation would qualify as lawful under the exceptions permitted by international treaties, as

95 Arbitrary deprivation of nationality: report of the Secretary-General. A/HRC/10/34, 26 January 2009, Para. 53.

96 Achiron, 2005, p. 39.

97 Expulsion of aliens. Memorandum by the Secretariat, International Law Commission, 58th session, A/CN.4/565, 10 July 2006, Para. 906.

98 Partial Award, Civilians Claims, Eritrea's Claims 15, 16, 23 \& 27-32, Eritrea-Ethiopia Claims Commission, The Hague, 17 December 2004.

99 Fourth report on the expulsion of aliens by Mr. Maurice Kamto, Special Rapporteur, International Law Commission, 60th session, A/CN.4/594, 24 March 2008, Para. 30.

100 Report of the International Law Commission, Sixty-sixth session (5 May-6 June and 7 July-8 August 2014), General Assembly Official Records, Sixty-ninth session, Supplement No. 10, A/69/10, Chapter IV, p. 33. 
long as the sole purpose of the depravation was to render the individual an alien and to expel that person from the territory of the State, it will still qualify as arbitrary deprivation, on account of the rule expressed in Draft Article 8, and hereby considered to be unlawful.

\subsection{The Role of ex post Effective Remedies}

When someone is actually deprived of his/her nationality, legal remedies against such a harsh intrusion into private life that can even destroy one's identity, are of outstanding importance. As a result, violations of the general prohibition of arbitrary deprivation of nationality must be open to an effective remedy. Persons having been arbitrarily deprived of their nationality must have access to legal avenues to challenge the validity of such acts, and to different kinds of ex post effective remedies, notably restoration of nationality as the principle remedy (preferably automatically); issuance of documents allowing the individual to make nationality effective as well as registration as a national in relevant civil registries. ${ }^{101}$ The UNHCR noted that in some cases arbitrary deprivation of nationality may be linked to past persecution against a specific group of people, in the refugee context. In such situations, following the change of circumstances in the country concerned, establishing a simple application procedure for re-acquisition of nationality of the once persecuted population seems to be appropriate, too. ${ }^{102}$

Following a thorough review of relevant hard law obligations in this matter, it is only the 1989 Convention on the Rights of the Child that is not silent in this regard. The CRC expressis verbis stipulates, in a relatively detailed manner, that '[w] here a child is illegally deprived of some or all elements of his or her identity [including nationality], State Parties shall provide appropriate assistance and protection, with a view to re-establishing speedily his or her identity' [Article 8(2)]. Besides this sole legally binding, specific obligation, a considerable set of soft law instruments have been developed later on. They evidence the emergence of a general norm of international law requiring effective remedies against arbitrary denationalization, not yet crystallized, but noticeably advancing towards universal acceptance. The UN Human Rights Council called upon States in subsequent resolutions to ensure that an effective remedy is available to persons who have been arbitrarily deprived

of their nationality, including but not limited to restoration of nationality. ${ }^{103}$ Likewise, a series of UNHCR ExCom conclusions have regularly addressed this issue, urging States to

101 Arbitrary deprivation of nationality: report of the Secretary-General. A/HRC/10/34, 26 January 2009, Para. 59; UNHCR, Human Rights and Arbitrary Deprivation of Nationality, Report of the Secretary-General, A/HRC/25/28, 19 December 2013, Para. 34; UNHCR, 'Tunis Conclusions', Para. 28.

102 UNHCR, 'Tunis Conclusions', Para. 29.

103 UN Human Rights Council resolutions 7/10 of 27 March 2008 (A/HRC/RES/7/10), operative Paras. 7; 10/13 of 26 March 2009 (A/HRC/RES/10/13), operative Paras. 2-3; or 20/5 of 16 July 2012 (A/HRC/RES/20/5), operative Para. 9. 
assist stateless persons in providing them with access to legal remedies to redress statelessness, in particular resulting from the arbitrary deprivation of nationality. ${ }^{104}$ However, practical obstacles often make it extremely difficult to benefit from the available legal remedies. Access to effective remedies normally relies on providing proof for personal identification, a task that can be seriously hampered by the effect of deprivation of nationality, especially if it rendered the person stateless. In this respect, both UNHCR and the UN Secretary General recommend States to envisage adopting flexible rules for evidence, facilitating proof of identity, which would allow the person concerned to provide witness testimony or resort to various sources of documentary evidence. ${ }^{105}$

\subsection{Deprivation of Nationality and EU Law: A Step Forward towards Enhanced Protection}

Switching the focus from international law ('father') to the EU legal order ('son'), the very first salient feature is that neither the founding treaties of the European Union, nor secondary EU law contain provisions on the acquisition or loss of Member States' nationality or the exercise of this right by States. Although both the Treaty on the European Union (TEU) and the Treaty on the Functioning of the European Union (TFEU) ${ }^{106}$ attach certain rights and entitlements to the possession of a nationality of the Member States, the EU Treaties do not regulate who and under which conditions shall be considered nationals of the Member States. In short, the EU still does not have competences in nationality matters, ${ }^{107}$ a matter of principle reaffirmed in Declaration No. 2 to Maastricht Treaty ${ }^{108}$ and the Edinburgh Decision of Heads of State and Government of 12 December 1992. ${ }^{109}$

However, EU lawyers know well the doctrine developed by the Court of Justice of the European Union (CJEU) in the famous Micheletti case, ${ }^{110}$ where the CJEU held: '[u]nder

104 E.g. UNHCR ExCom conclusions No. 102 (LVI) 2005, Para. (y); No. 106 (LVII) 2006, Para. (v).

105 Arbitrary deprivation of nationality: report of the Secretary-General. A/HRC/10/34, 26 January 2009, Paras. 59, 68; Human Rights and Arbitrary Deprivation of Nationality, Report of the Secretary-General. A/HRC/13/34, 14 December 2009, Para. 46.

106 Consolidated versions of the Treaty on European Union and the Treaty on the Functioning of the European Union, OJ C 83, 30 March 2010, pp. 1-388.

107 See Arts. 4 and 6 TFEU.

108 Declaration No. 2 annexed to the Treaty of Maastricht on nationality of a Member State (OJ C 191, 29 July 1992, p. 98).

109 Denmark and the European Union, Annex I (Decision of Heads of State and Government, meeting within the European Council, concerning certain problems raised by Denmark, on the Treaty on the European Union), Section A - Citizenship (OJ C 348, 31 December 1992, p. 1).

110 Case C-369/90, M. V. Micheletti and others v. Delegacion del Gobierno en Cantabria, Judgement of 7 July 1992, ECR [1992] p. I-4239. For a detailed analysis of the judgment, see e.g. H.U. Jessurun d'Oliveira, Case Note (Case C-369/90. M. V. Micheletti and others v. Delegación del Gobernio en Cantabria, Judgment of 7 July 1992, not yet reported), 30 Common Market Law Review (1993), pp. 623-637; D. Ruzié, 'Nationalité, effectivité et droit communautaire’, 97 Revue générale de droit international public (1993), pp. 107-120. 
international law, it is for each Member State, having due regard to Community law, to lay down the conditions for the acquisition and loss of nationality'. ${ }^{111}$ Interestingly, despite the explicit reference to international law, thus implicitly recognizing that the term 'nationality' does not have a specific definition under EU law, ${ }^{112}$ the first part of this formula does not follow the concept of the 1930 Hague Convention. In the latter, the limitations on States' sovereign prerogatives in nationality issues operate on the international plane, i.e. the legal effects towards other States of a given nationality can be restricted and other States are entitled to not recognize such a nationality if it violates certain standards stemming from international law. Yet, in Micheletti, the CJEU placed restrictions, of EU law origin, on the internal exercise - regulating the loss and acquisition of nationality in the domestic sphere - of the States' exclusive competence concerning nationality matters. This difference can also be explained by the level and focus of regulation as well as the field of application of the rules of the respective legal systems: international law is still mainly an inter-State legal order of co-ordination (horizontal structure) while EU law traditionally and extensively addresses intra-State issues and situations, directly affecting the domestic legal life of Member States (dominantly a vertical structure, similar to municipal law in this regard).

Then comes the pressing question: what does 'having due regard to Community law' mean? Given that subsequent judgments of the CJEU dealing with similar matters only repeated this phrase and failed to clarify its meaning and consequences, ${ }^{113} \mathrm{EU}$ law scholars have tried to elaborate more on it. On the basis of those academic writings, the following prohibitions (or in other words: requirements) may be formulated towards domestic legislation or practice in nationality matters: 1) Member States' nationality legislations should not violate fundamental rights enshrined in the EU Charter of Fundamental Rights or as general principles of law interpreted by the jurisprudence of the $\mathrm{CJEU}^{114} ; 2$ ) domestic

111 Ibid., Para. 10 (emphasis added).

112 See the Opinion of Advocate-General Tesauro delivered on 30 January 1992 in the Micheletti case, ECR [1992] p. I-4254, Para. 3 ('As yet there is no Community definition of nationality; the provisions of Community law which require an individual to possess the 'nationality' of a Member State as a prerequisite for their application must be understood as referring to the national law of the State whose nationality serves as the basis of the right relied upon').

113 E.g. Case C-179/98, Belgian State v. Mesbah, Judgment of 11 November 1999, ECR [1999] p. I-7955; Case C-192/99, The Queen contra Secretary of State for the Home Department, ex parte: Manjit Kaur, Judgment of 20 February 2001, ECR [2001] p. I-1237; Case C-200/02, Kunqian Catherine Zhu and Man Lavette Chen v. Secretary of State for the Home Department, Judgment of 19 October 2004, ECR [2004], p. I-9925.

114 S. O'Leary, 'Nationality and Community Citizenship: A Tale of Two Uneasy Bedfellows', 12 Yearbook of European Law (1992), p. 356; H.U. Jessurum d'Oliviera, 1993, pp. 636-637; S. Hall, Nationality, Migration Rights and Citizenship of the Union, Martinus Nijhoff Publishers, Dordrecht-Boston-London, 1995, pp. 5657; G-R. de Groot, 'The Relationship between the Nationality Legislation of the Member States of the European Union and European Citizenship', in M. La Torre (Ed.), European Citizenship: An Institutional Challenge [The European Forum 3], Kluwer Law International, The Hague-London-Boston, 1998, p. 124. 
nationality laws should not violate the so-called loyalty clause [Article 4(3) TEU $]^{115}$; 3) Member States should not exercise en masse naturalization to certain populations without prior consultation with EU partners (e.g. in respect of minorities living in countries neighboring the kin-State) which could be in breach of the principle of solidarity [Article $3(3) \mathrm{TEU}]^{116}$; 4) nationality policies must be in conformity with the territorial scope of the Treaties [Article 52 TEU, Article 355 TFEU] (e.g. not excluding British Dependent Citizens living in Gibraltar from 'UK citizens' ${ }^{117}$; and finally 5) loss of Member State nationality is not permissible because of long-term residence in other Member State, ${ }^{118}$ in order to respect freedom of movement of EU citizens as one of the four Union freedoms, a cornerstone of European integration.

This ambiguous legal situation has significantly changed with the landmark judgment of the CJEU rendered in the Rottmann case (2010). ${ }^{119}$ As per the factual background of the case, Janko Rottmann, originally an Austrian national, exercised his right of free movement and moved to Germany in 1995 (apparently before criminal sanctions could be applied). Three years later he applied for German nationality, without disclosing to the German authorities that criminal proceedings have been instituted against him. German nationality was granted to Mr. Rottmann in 1999, and by way of naturalization he lost his Austrian nationality ex lege, in line with Austrian nationality law. However, the Austrian authorities informed the city of Munich, which had handled the request for naturalisation, about the criminal proceedings against Rottmann in Austria. As a result, Germany revoked the naturalisation decision on the grounds that it had been obtained fraudulently. The effect of the withdrawal of German nationality, which did not entail automatic reacquisition of Austrian nationality under Austrian law, would render Rottmann stateless (losing also his status of EU citizen). ${ }^{120}$ This scenario finally offered the CJEU a good opportunity to explain the scope and exact meaning of the expression 'having due regard to [European Union] law'. If we put the legal reasoning into a logical sequence, the following can be depicted. First, the Court echoed the general rules of international law applicable to the case, i.e. that the rules on the acquisition and loss of nationality fall within the competence

115 O’Leary, 1992, p. 379; Hall, 1995, pp. 64-73; de Groot, 1998, pp. 123, 135.

116 Hall, 1995, pp. 67, 73.

117 de Groot, 1998, p. 135.

118 O’Leary, 1992, pp. 366, 378; Hall, 1995, p. 33; de Groot, 1998, pp. 123, 136-147; G-R. de Groot, 'Towards a European Nationality Law', 8(3) Electronic Journal of Comparative Law (October 2004), p. 8.

119 Case C-135/08, Janko Rottmann v. Freistaat Bayern, Judgment of 2 March 2010, ECR [2010], p. I-1449.

120 The summary of facts has been based on H. van Eijken, 'European Citizenship and the Competence of Member States to Grant and to Withdraw the Nationality of their Nationals', 27(72) Merkourios (2010), Case Note, pp. 65-69; J. Shaw, 'Setting the Scene: The Rottmann Case Introduced', in J. Shaw (Ed.), 'Has the European Court of Justice Challenged Member State Sovereignty in Nationality Law?', EUI Working Papers, RSCAS 2011/62 (December 2011), p. 1; and the résumé of the case on the EUDO Observatory on Citizenship, available at: http://eudo-citizenship.eu/databases/citizenship-case-law (last accessed on 1 July 2014). 
of the Member States and arbitrary deprivation of nationality is prohibited. ${ }^{121}$ Second, it drew attention to applicable EU law in this specific field of national competence, emphasizing the well-established horizontal rule in its case-law: even if a 'matter falls within the competence of the Member States [...], in situations covered by European Union law, the national rules concerned must have due regard to the latter'. ${ }^{122}$ Given that deprivation of nationality causes also the loss of EU citizenship and the rights attached to it, this situation falls within the ambit of EU law, by reason of its nature and consequences. ${ }^{123}$ This clearly showcases the wide reach of EU citizenship as construed by the Court. Third, the CJEU turned its attention to the legal ramifications of the general ban not to arbitrarily deprive a person of his/her nationality under EU law. In this context, it reminded that ' $[w]$ hen a State deprives a person of his nationality because of his acts of deception, legally established, that deprivation cannot be considered to be an arbitrary act', ${ }^{124}$ then reached the conclusion that deprivation of nationality is not contrary to EU law as long as it is in line with international law. Nevertheless, the CJEU introduced a supplementary requirement, an additional standard of review when assessing the legality of an act of withdrawal of nationality: the proportionality test. Quite disputably, the proportionality test has not been conducted by the Court itself, but it is to be done by the national court, which in my view quite undermines the uniform application of EU law, especially in situations where the supranational, autonomous legal status of EU citizenship is at stake. ${ }^{125}$ So as to guide national courts, the CJEU identified pertinent elements to take into account when examining a decision withdrawing naturalisation against the principle of proportionality. These are the following: 1) the consequences that the decision entails for the person concerned and, if relevant, for the members of his family; 2) the gravity of the offence committed by that person; 3) the lapse of time between the naturalisation decision and the decision on withdrawal; and finally 4) the possibility to recover the original nationality (including examining whether, having regard to all relevant circumstances, the person should be afforded a reasonable period of time in order to try to recover the nationality of his Member State of origin). ${ }^{126}$ 'This latter factor seems to hint at some relationship of cooperation needing to emerge between Member States in these circumstances' - notes Professor Shaw. ${ }^{127}$ Two further remarks should be made. The first is a seemingly technical one, about terminology: the CJEU did not borrow the traditional term for this kind of involuntary loss of nationality

121 Rottmann judgment, Paras. 14, 39, 53.

122 Ibid., Para. 41.

123 Ibid., Para. 42.

124 Ibid., Para. 53.

125 See also D. Kochenov, 'Two Sovereign States vs. a Human Being: CJEU as a Guardian of Arbitrariness in Citizenship Matters', in J. Shaw (Ed.), 'Has the European Court of Justice Challenged Member State Sovereignty in nationality law?', EUI Working Papers, RSCAS 2011/62 (December 2011), p. 14.

126 Ibid., Paras. 56, 58.

127 Shaw, 2011, p. 4. 
from international law ('deprivation'), but consistently used 'withdrawal' which might be explained by the Court's endeavour to accentuate the autonomous nature of EU law and its legal terms vis-à-vis international law. Second, on a more substantial note, decisions on withdrawal of nationality can be subject to judicial review before the Court of Justice of the $E U$, acting as final arbiter. The question is whether this also holds true when a particular Member State excludes the judicial review of withdrawal decisions by national courts, e.g. having made a reservation to the 1997 ECN in this respect? Against this background, it is even more interesting how far reaching implications can be deduced from the next statement of the Luxembourg Court:

[t]he proviso that due regard must be had to European Union law [...] enshrines the principle that, in respect of citizens of the Union, the exercise of [the power to lay down the conditions for acquisition/loss of nationality], in so far as it affects the rights conferred and protected by the legal order of the Union, as is in particular the case of a decision withdrawing naturalisation [...] is amenable to judicial review carried out in the light of European Union law. ${ }^{128}$

Summing it up, in the Rottmann judgment, the Court of Justice of the European Union elaborated more on the procedural standards of the lawful deprivation of nationality, notably by incorporating proportionality as a general principle of EU law ${ }^{129}$ into the assessment of the arbitrariness of deprivation of nationality as well as foreseeing judicial review before the CJEU and via national courts, in light of EU law. But all this merely applies in relation to acts of deprivation of nationality resulting in statelessness, which only constitutes, as described above, one manifestation of arbitrariness when a nationality is withdrawn. With regard to the nature of arguments, in the context of the deprivation of nationality, the Court did not focus on a human rights imperative to avoid statelessness, but on the specific, supranational legal status of the individual ${ }^{130}$ and the rights stemming from EU citizenship, which is the 'fundamental status of nationals of the Member States'. Some say that 'Rottmann went [...] on fetishizing the few similarly exceptions from the main rule of international law on avoidance of statelessness', adding that the 'Court is seemingly technical and cold blooded. ${ }^{131}$ By contrast, I find that the technical approach was somewhat unavoidable and necessary, since it was solely through the lenses of EU

128 Ibid., Para. 48.

129 See in the same way G.T. Davies, 'The Entirely Conventional Supremacy of Union Citizenship and Rights', in J. Shaw (Ed.), Has the European Court of Justice Challenged Member State Sovereignty in Nationality Law?', EUI Working Papers, RSCAS 2011/62 (December 2011), p. 9.

130 Shaw, 2011, p. 3.

131 Kochenov, 2011, p. 14. 
citizenship that the Court could find jurisdiction ratione materiae in this case and this thin ice did not realistically allow for more.

\subsection{Concluding Remarks}

After having analysed the concept and content of the prohibition of arbitrary deprivation of nationality under international law and EU law, looking for new perspectives, some general concluding remarks can be phrased. First, we have seen that it is still a topic of particular importance, even nowadays, in the era of global human rights. As the UK Supreme Court eloquently concluded:

[a]lthough the international growth of human rights during the past fifty years has to some extent succeeded in establishing that a person's right to have rights stems, instead, from his existence as a human being, worldwide legal disabilities with terrible practical consequences still flow from lack of nationality. ${ }^{132}$

Currently, besides the quite solid international legal framework, leaving extremely restricted room for States to deprive persons of their nationality, noteworthy policy developments can be seen on the universal plane. The United Nations and its different bodies have started putting more emphasis on this topic in the framework of the international human rights agenda since the new millennium, which is marked by the proliferation of the resolutions of the UN General Assembly, the UN Human Rights Council and the UNHCR Executive Committee, not to mention the extensive groundwork laid down by the Office of the High Commissioner of Human Rights as well as various reports of the UN Secretary General. Recently, the Human Rights Council had engaged in collecting information from States until mid-2013, then a larger and richer State practice was made available by the end of $2013 .{ }^{133}$ Proportionality appears to be a new element in the assessment of arbitrariness, not only as an advocacy tool used by UNHCR and other UN agencies as well as human rights NGOs working in this field, but first confirmed in international jurisprudence, in a legally binding way, albeit limited to European legal realities. At any rate, this development is not to be underestimated, which is well illustrated by Laura van Waas's thoughts from the pre-Rottmann period:

132 Secretary of State for the Home Department (Appellant) v. Al-Jedda (Respondent), Judgment of 9 October 2013 [2013] UKSC 62, Para. 12.

$133 \mathrm{See}$ the latest report of the UN Secretary General on human rights and arbitrary deprivation of nationality (A/HRC/25/28, 19 December 2013). 
[i]t is certainly true that to permit the loss or deprivation of nationality in the knowledge that this will lead to statelessness is becoming increasingly unacceptable and is deemed by some to amount to (prohibited) arbitrary deprivation of nationality. However, until an international [...] treaty body or court explicitly address this question, it will remain unclear in which exact circumstances the creation of statelessness in this manner is or is not permissible. ${ }^{134}$

As a soft form of interaction between EU law and international law, the principle of proportionality, brought up by the CJEU, infiltrated the international policy-making agenda and appeared in universal documents such as various reports prepared by the UN Secretary General ${ }^{135}$ or the UNHCR interpretative guidance (cf. the 'Tunis Conclusions'). ${ }^{136}$ As far as the $\mathrm{EU}$ is concerned, the additional requirements formulated by Rottmann in order to avoid statelessness as an emanation of arbitrary deprivation of nationality represent an important step forward towards an enhanced protection of core human rights such as the right to a nationality, even if emerging rather as a side effect of a reasoning first and foremost shielding EU citizens and their rights. The EU also needs more coordination with the Council of Europe, which has without doubt the greatest expertise in nationality matters; such coordination is likely to be intensified in the near future. ${ }^{137}$ In my assessment everything is granted for a greater convergence between regional and universal legal standards, with a view to combating arbitrary deprivation of nationality around the globe, always keeping in mind that any interference with the enjoyment of nationality has a significant, often disastrous, impact on the enjoyment of basic human rights.

134 van Waas, 2008, p. 90.

135 See the most recent report of the UN Secretary-General on human rights and arbitrary deprivation of nationality (A/HRC/25/28, 19 December 2013), Paras. 4, 39, 40.

136 Paras. 19-24.

137 The recent activity of the Parliamentary Assembly of the Council of Europe is promising, see e.g. Access to nationality and the effective implementation of the European Convention on Nationality - Report (Doc. 13392, 23 January 2014, Committee on Legal Affairs and Human Rights, Rapporteur: Mr. Boriss Cilevics), then Resolution 1989 (2014) on Access to nationality and the effective implementation of the European Convention on Nationality and Recommendation 2042 (2014) Access to nationality and the effective implementation of the European Convention on Nationality (both adopted on 9 April 2014). 